\title{
RNAseq analysis of treatment-dependent signaling changes during inflammation in a mouse cutaneous wound healing model
}

Georges St. Laurent $1 \mathrm{II}^{1,2^{\wedge}}$, lan Toma ${ }^{3}$, Bernd Seilheimer ${ }^{4}$, Konstantin Cesnulevicius ${ }^{4}$, Myron Schultz ${ }^{4}$, Michael Tackett ${ }^{1,2}$, Jianhua Zhou ${ }^{1}$, Maxim Ri ${ }^{1,5}$, Dmitry Shtokalo ${ }^{1,5,6}$, Denis Antonets ${ }^{5,6}$, Tisha Jepson ${ }^{1,2}$ and Timothy A. McCaffrey ${ }^{3^{*}}$

\begin{abstract}
Background: Despite proven therapeutic effects in inflammatory conditions, the specific mechanisms of phytochemical therapies are not well understood. The transcriptome effects of Traumeel (Tr14), a multicomponent natural product, and diclofenac, a non-selective cyclooxygenase (COX) inhibitor, were compared in a mouse cutaneous wound healing model to identify both known and novel pathways for the anti-inflammatory effect of plant-derived natural products.

Methods: Skin samples from abraded mice were analyzed by single-molecule, amplification-free RNAseq transcript profiling at 7 points between 12 and $192 \mathrm{~h}$ after injury. Immediately after injury, the wounds were treated with either diclofenac, $\operatorname{Tr} 14$, or placebo control ( $n=7$ per group/time). RNAseq levels were compared between treatment and control at each time point using a systems biology approach.

Results: At early time points (12-36 h), both control and Tr14-treated wounds showed marked increase in the inducible COX2 enzyme mRNA, while diclofenac-treated wounds did not. Tr14, in contrast, modulated lipoxygenase transcripts, especially ALOX12/15, and phospholipases involved in arachidonate metabolism. Notably, Tr14 modulated a group of cell-type specific markers, including the T cell receptor, that could be explained by an overarching effect on the type of cells that were recruited into the wound tissue.

Conclusions: $\operatorname{Tr} 14$ and diclofenac had very different effects on the COX/LOX synthetic pathway after cutaneous wounding. Tr14 allowed normal autoinduction of COX2 mRNA, but suppressed mRNA levels for key enzymes in the leukotriene synthetic pathway. Tr14 appeared to have a broad 'phytocellular' effect on the wound transcriptome by altering the balance of cell types present in the wound.
\end{abstract}

Keywords: Inflammation, Transcriptome, RNA sequencing, Traumeel, Diclofenac, Cyclooxygenase, Lipoxygenase, Phospholipase

\footnotetext{
* Correspondence: mcc@gwu.edu

Georges St. Laurent III is deceased.

${ }^{3}$ Department of Medicine, Division of Genomic Medicine, The George

Washington University Medical Center, 2300 Eye St, Washington D.C 20037,

USA

Full list of author information is available at the end of the article
}

(C) The Author(s). 2021 Open Access This article is licensed under a Creative Commons Attribution 4.0 International License, which permits use, sharing, adaptation, distribution and reproduction in any medium or format, as long as you give appropriate credit to the original author(s) and the source, provide a link to the Creative Commons licence, and indicate if changes were made. The images or other third party material in this article are included in the article's Creative Commons licence, unless indicated otherwise in a credit line to the material. If material is not included in the article's Creative Commons licence and your intended use is not permitted by statutory regulation or exceeds the permitted use, you will need to obtain permission directly from the copyright holder. To view a copy of this licence, visit http://creativecommons.org/licenses/by/4.0/ The Creative Commons Public Domain Dedication waiver (http://creativecommons.org/publicdomain/zero/1.0/) applies to the data made available in this article, unless otherwise stated in a credit line to the data. 


\section{Background}

The complex physiological events that comprise the acute wound healing process may be central to understanding the biological mechanisms of chronic disease. Tissue injury and healing mechanisms share remarkable similarities in different organs [1]. Even in cancer, the importance of tissue remodeling has led authors to describe tumors as having a component of "wounds that do not heal" [2]. Transcriptome-based studies have revealed inflammatory molecular signatures in many diseases, and precisely defined many of the inflammatory events that dominate the early stages of tissue repair [3]. Detailed analysis of wound dynamics over time is beginning to redefine chronic disease states. For example, the discovery of the resolvins and their actions within the inflammation system have suggested that injury "resolution" is a defining event between "acute" and "chronic" inflammation $[4,5]$.

The present study interrogates a high-resolution map of the mouse transcriptome during wound healing to define changes resulting from therapeutic intervention with Traumeel (Tr14), a well-known natural multicomponent anti-inflammatory medicinal product for musculoskeletal conditions. Natural products can have a broad spectrum of important biological effects ranging from the antimitotic and anticancer effects of taxol, purified from the Pacific yew tree bark (Taxus brevifolia), to the antiinflammatory effects of aspirin, a non-steroidal antiinflammatory drug (NSAID), derived from precursors in willow tree bark (genus Salix). Natural products have been used for millennia to inhibit inflammation in various forms, and may target multiple points in the inflammation pathways [6], including the prostaglandin/ leukotriene pathways $[7,8]$. Prior studies have demonstrated that $\operatorname{Tr} 14$ inhibits IL- $1 \beta$ and TNF- $\alpha$ production by resting and activated immune cells in vitro [9], and has antioxidative properties [10]. In clinical studies, $\operatorname{Tr} 14$ has shown effects on cytokine levels in exercise-induced muscle injury [11, 12], and demonstrated pain relief in acute ankle sprains [13]. NSAIDs, such as diclofenac, have a fairly well-defined mechanism of action via cyclooxygenase inhibition. However, NSAIDs have diverse secondary effects that might be better understood by characterizing their effects on the transcriptome $[14,15]$. We have previously reported the transcriptome-wide analysis of $\operatorname{Tr} 14$ therapeutic effects in the mouse wound healing model [3]. The present studies were conducted to compare and explore more specifically the antiinflammatory effects of $\operatorname{Tr} 14$ and diclofenac at the transcriptome level.

\section{Results}

\section{Global signature of diclofenac versus $\operatorname{Tr} 14$}

The overall similarities and differences between the two types of therapy were evaluated by statistically identifying differentially expressed genes (DEGs) and then organizing the DEGs according to Gene Ontologies to identify any systematic patterns of change as shown schematically in Fig. 1 (all DEGs listed in Suppl. Table 1). In general, diclofenac induced a larger number of expression changes compared to Tr14, when similar statistical filters were applied (Fig. 2). This was mainly observed at the earlier time points of $12-36 \mathrm{~h}$ post-injury, where diclofenac altered as much as 10 times as many transcripts as Tr14 (36 h, 1840 vs 162 DEG). By 72-96 h however, Tr14 altered about 3 times more transcripts than diclofenac, with the effects roughly balanced by $96-$ $120 \mathrm{~h}$ (Fig. 2). When the specific DEGs between groups were compared, there were 25-123 common transcripts altered by both of the treatments, that reflected roughly $10-50 \%$ overlap between the DEGs at any given time point (Fig. 2). That degree of overlap is 5.6 to 30 -fold greater than expected by chance, with the odds of such an overlap occurring by chance alone being extremely small, with a range of $p=2.2 \times 10^{-18}(24 \mathrm{~h})$ to $8.4 \times 10^{-189}(96 \mathrm{~h})$ by Fisher's exact test. Thus, the two treatments affected both shared and unique RNA transcripts over time.

\section{Bioinformatic analysis of diclofenac and Tr14-modulated transcripts}

The types of transcripts affected by each treatment over time were classified into pre-curated gene ontologies (GO) according to their functions. Tr14 induced a clusters of transcripts related to lipid/steroid biosynthesis and translation initiation in the $12-72 \mathrm{~h}$ timeframe, that were not observed to increase in diclofenac-treated wounds. Both clusters are presented in Fig. 3 as Cluster 3 (green) and Cluster 4 (purple) respectively. When sorted by their relevant gene ontologies, diclofenac had early effects at $12-24 \mathrm{~h}$ on transcripts related extracellular matrix, cell migration, innate immunity, and the ribosome. However, by $36 \mathrm{~h}$, this transitioned into effects on the ribosome and translation with waning effects on extracellular matrix transcripts. In contrast, Tr14 had less striking effects on these pathways in the $12-36 \mathrm{~h}$ period, while in the later timeframe of 72 to $192 \mathrm{~h}$, Tr14 altered transcripts related to extracellular matrix, innate immunity, inflammation, and translation (Fig. 3). Thus, while many of the same transcripts and the same systems are altered by diclofenac and $\operatorname{Tr} 14$, there was a striking temporal dissociation, with $\operatorname{Tr} 14$ showing a delayed effect.

A more detailed examination of the types of transcripts affected by Tr14 points to five 'SuperClusters' of transcripts related to immune function and inflammation, extracelular matrix, ion transport, G protein signaling, and lipid/steroid metabolism (Fig. 4). Each of these 


\begin{tabular}{|c|c|c|}
\hline 4 treatment groups & Experimental protocol & Analysis \\
\hline Abraded + placebo topical (PT) & 1 Anesthetize mouse & $\begin{array}{l}1 \text { Alignment to } \\
\text { mm10 mouse genome }\end{array}$ \\
\hline Abraded + diclofenac topical (DT) & 2 Shave dorsal skin & 2 Filter \\
\hline Abraded + saline injection (SI) & free of hair & \\
\hline Abraded + Tr14 topical + injection (TTI) & $\begin{array}{l}3 \text { Abrade shaved } \\
\text { area }\end{array}$ & $\begin{array}{l}3 \text { Count sequence } \\
\text { reads aligning to each } \\
\text { UCSC transcript }\end{array}$ \\
\hline & 4 Apply agents & 4 Compare treated to \\
\hline 7 animals/time/treatment & $\begin{array}{l}5 \text { Harvest tissue at } \\
\text { specified times }\end{array}$ & $\begin{array}{l}\text { control group for } \\
\text { differentially } \\
\text { expressed genes (DEG) }\end{array}$ \\
\hline 0 Hour +7 time points of treatment & $\begin{array}{l}6 \text { Isolate and purify } \\
\text { RNA, deplete }\end{array}$ & $\begin{array}{l}5 \text { Sort DEGs for } \\
\text { enrichment of specific } \\
\text { gene ontologies (GO) }\end{array}$ \\
\hline $0,12,24,36,72,96,120$, and 192 hours & $\begin{array}{l}7 \text { Generate and } \\
\text { tail cDNA }\end{array}$ & $\begin{array}{l}6 \text { Analyze DEGs for } \\
\text { changes in biological } \\
\text { pathways }\end{array}$ \\
\hline 195 samples a & $\begin{array}{l}8 \text { Sequence on Helicos/ } \\
\text { SeqLL Single Molecule } \\
\text { Sequencer (SMS) }\end{array}$ & $\begin{array}{l}\text { published and cell } \\
\text { type specific genes }\end{array}$ \\
\hline
\end{tabular}

Fig. 1 Schematic diagram of study design. The overall study design is summarized schematically to describe the groups, the wounding model, RNAseq analysis, and bioinformatic analysis

5 SuperClusters would be highly relevant to the control of inflammation. Lipid/steroid metabolism, ion transport, and $\mathrm{G}$ protein signaling are major pathways that modulate inflammatory signaling and extracelular matrix production. For instance, many of the pro-inflammatory and anti-inflammatory pathways utilize small lipid intermediates that are known to regulate inflammatory and extracelular matrix genes.

\section{Effects on the eicosanoid pathway transcripts}

The eicosanoid pathway is a well characterized system involving enzymatic production of a variety of small lipid intermediates with pro- and anti-inflammatory effects. The eicosanoid pathway is a known target of NSAIDs, such as diclofenac, and thus, it was interesting to evaluate the effect of these two treatment types on the RNA transcripts in those pathways. Two major pathways of eicosanoid generation involve several catalytic conversions of arachidonic acid into bioactive agents via cyclooxygenases (COX1/2, PGH synthase 1/2, PTGS1/2) and lipoxygenases (LOX) (Fig. 5). In each pathway, several downstream enzymatic steps can significantly alter the biological activity of the eicosanoids in a tissue-specific manner. To examine how these pathways were affected at the mRNA level, the DGE of the enzymes was analyzed in the time series data and compared between treatment groups. At the 24-h time point, for example, diclofenac and $\operatorname{Tr} 14$ had very different patterns of changes in COX/LOX-related enzyme mRNAs, showing essentially opposite effects on the modulation of key enzymes such as 5lipoxygenase (ALOX5), and the phospholipases (Pla2) that are essential for the liberation of arachidonate from the cell membranes. The later time points demonstrate persistent differences in the effects on the COX/LOX pathways (Supplementary Figs. 1-6).

Furthermore, in control wounds, RNAseq detected a strong and well known increase in the inducible PGH synthase 2 mRNA (COX-2, Ptgs1/2) 12-24 h after injury (not shown). As expected from inhibition of the downstream feedback signal, especially PGE2, diclofenac caused an almost 4-fold reduction in COX-2 mRNA expression at early time points, while $\operatorname{Tr} 14$, however, did not block COX-2 mRNA induction, which was $1.5 \mathrm{X}$ greater than control levels at $24 \mathrm{~h}$ (Fig. 5).

\section{Pathway analysis of Tr14 versus diclofenac on the pro- inflammatory and pro-resolution eicosanoids}

Assembling the above RNA changes in relation to their predicted production of eisosanoids, it is possible to visualize the broad differences between the two agent's effects on the key pathways in tissue homeostasis and repair. As shown in Fig. 6, NSAIDs such as diclofenac, have relatively specific effects that 


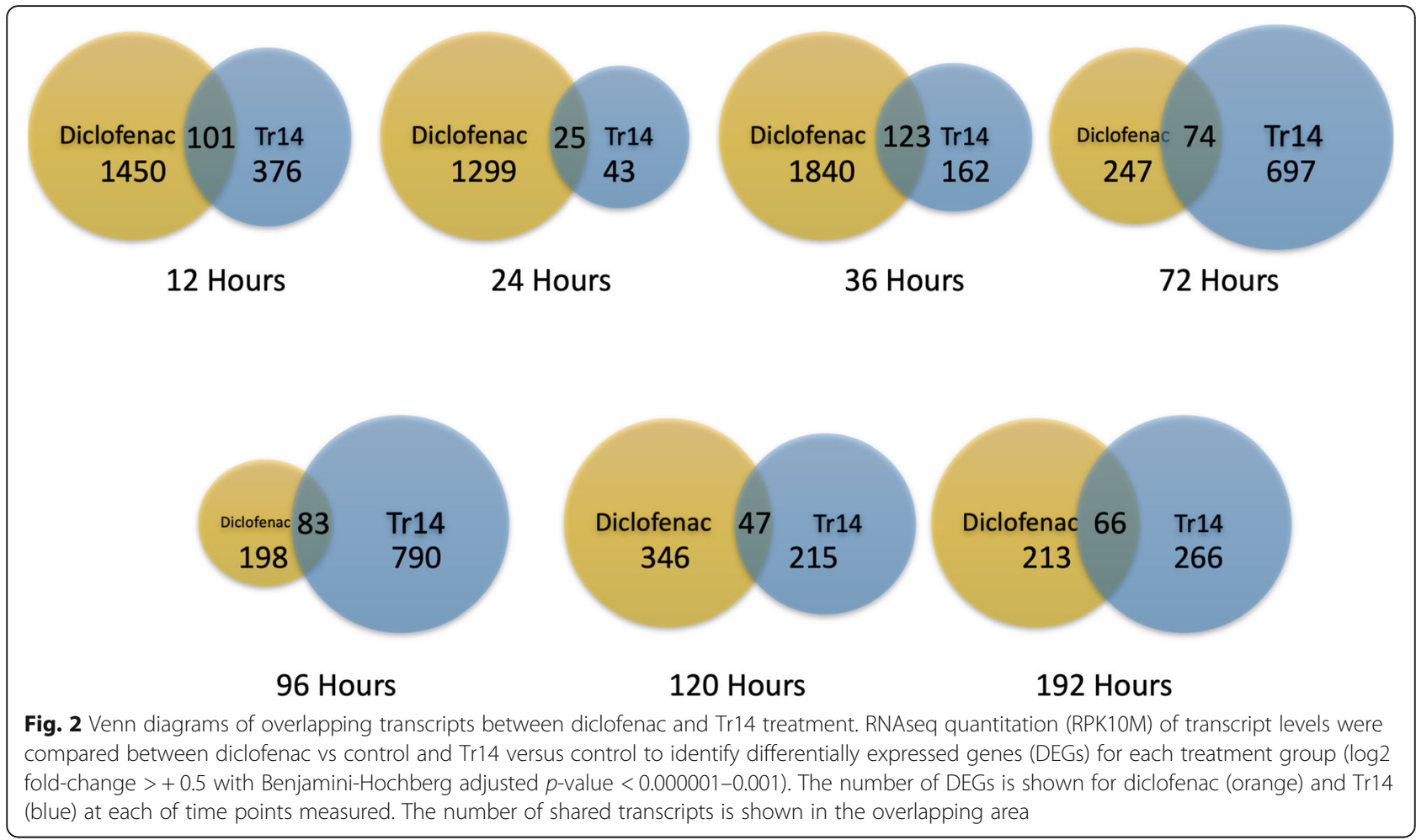

inhibit the constitutive and inducible COX enzymes, leading to marked reduction in the downstream products PGI2, TBXA2, PGD2, and PGE2. This direct inhibitory effect has the effect of shunting AA into the lipoxygenase pathway, which includes many proinflammatory eicosanoids in the leukotriene pathway, but also into the lipoxin pathway which could have beneficial, pro-resolution effects. In contrast, Tr14 has no direct inhibitory effect on COX enzymes, and because downstream mediators such as PGE2 are not impaired, there is a normal and expected increase in COX2/PTGS2 enzyme that is evident at the mRNA level measured here. It is possible that the absence of direct anti-COX activity by $\operatorname{Tr} 14$ allows the proresolution eicosanoids in that pathway, such as PGI2, PGD2, and PGE2 to exert normal repair functions in proportion to the normal leukotriene and lipoxin pathways.

\section{Analyzing Tr14 DEGs as markers of migratory cell types in the wound}

While manually curating the Tr14 DEGs that were strongly affected early after injury, there was an apparent effect on transcripts that have been previously recognized as markers of particular immune cell types. For example, even at the $12-\mathrm{h}$ time point, Tr14 produced notable effects of up to 17 -fold on transcripts associated with T cells such as Dusp14, Fbp1, Ly6a, Ly86, and Sla2 (Table 1). Additionally, several of the Tr14-modulated transcripts were known cell-type markers for the $\mathrm{T}$ regulatory subset (Treg), especially FoxP3 and Gata3. Other markers, such as Defb4 (neutrophil) and caldesmon 1 (macrophage) suggest enhanced migration of other immune cell types. While is possible that these transcripts could also be a markers of other resident cell types, collectively they seem to suggest differential migration of immune cells into the wound.

These early, strongly modulated transcripts have a common thread of potentially reporting the type of cells that are entering the wound. Related DEGs were also observed that effect cell-cell signaling, adhesion, migration, and intercellular junctions in the wound. As summarized in Fig. 7, these cell type markers may be reporting the types of cells entering the wound, and then other markers are reporting changes in the way that they interact with the wound, especially by altered cell-cell communication. For example, Dusp14 is $\mathrm{T}$ cell-associated transcript that negatively regulates $\mathrm{T}$ cell receptor (TCR) activation [17]. Other transcripts such as Fbp1 are important in the Nrf2 stress pathway, Stra6 is involved in vitamin A transport in a murine psoriasis model [18], and 2 transmembrane proteases (Tmprss11e/f) are involved in skin barrier function. Other transcripts likely relate to altered intercellular adhesion and migration of immune repair cells, such as cathepsin E, which, as noted, is a neutrophil/T cell factor involved in antigen processing, but is also involved in cell migration. Claudin 8 


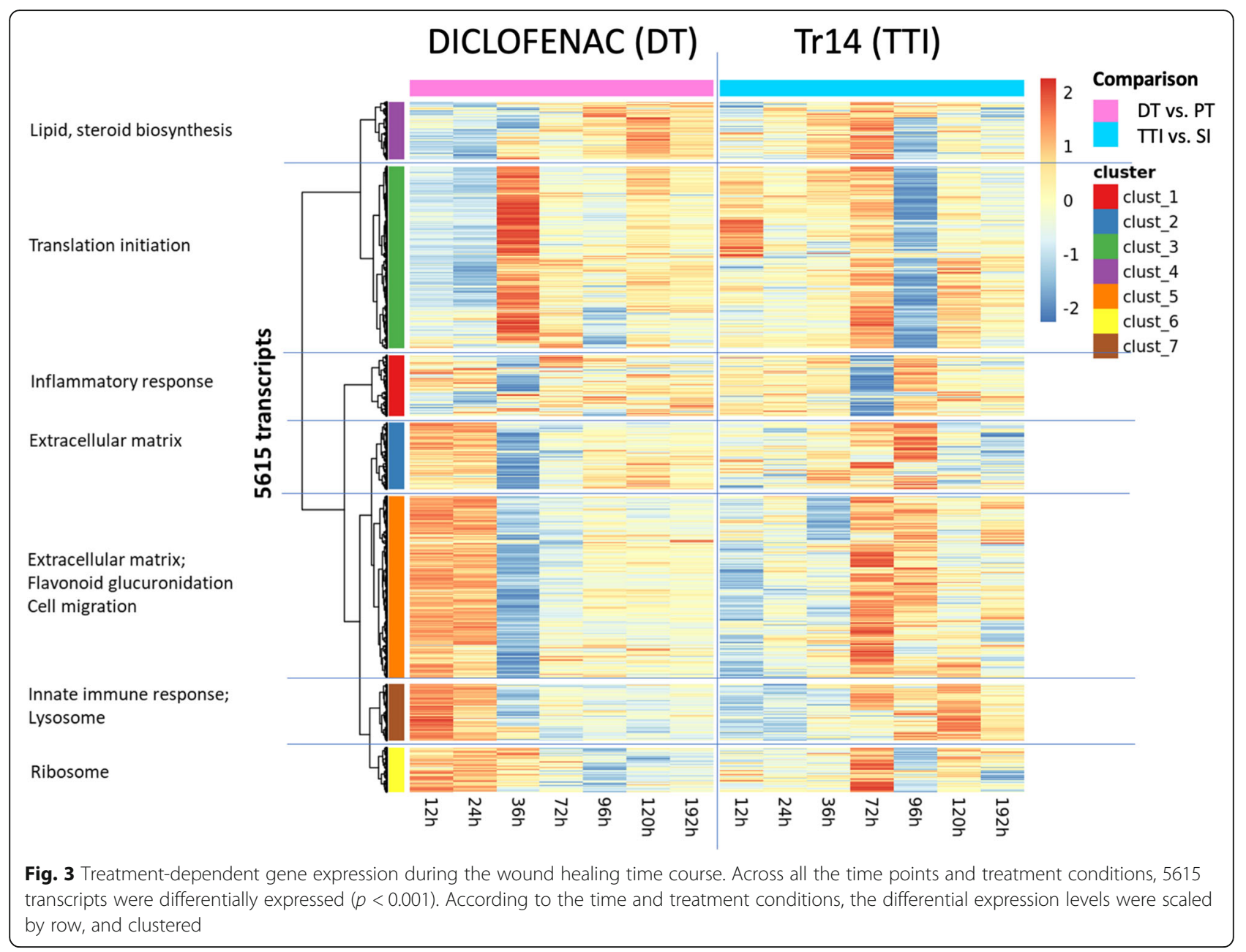

(Cldn8) is a known epidermal protein involved in tight junctions, and was identified by RNAseq as being relevant to the immune response in atopic dermatitis and psoriasis [19]. Other transcripts are likely related to follicular (Pla2g2e, Prss53) and keratinocyte (Exph5) adhesion and migration, and Pla2g2e has been specifically related to skin disorders such as epidermolysis bullosa and skin fragility [20].

\section{Comparison of the present dataset to prior studies}

The transcriptomic effects of diclofenac have been examined by others, and the present results were compared with the transcriptome analysis of diclofenac treatment of mice by Chung et al. [15]. These authors examined the effect of a single, oral dose of diclofenac ( 9.5 or $0.95 \mathrm{mg} / \mathrm{kg}$ body weight) on the liver transcriptome at 6,24 , and $72 \mathrm{~h}$ post-treatment. RNA levels were quantified by microarray, and then 2-way ANOVA was used to identify DEGs. They identified 2 primary pathways that were affected, eicosanoid metabolism and apoptosis, and the present results can confirm some of the changes that they observed. Notably, in the eicosanoid pathway, both studies observed induction of the group $12^{\text {a }}$ secretory phospholipase A2 isoform 1 (Pla2g12a, similar to Fig. 5 Pla2g), which in the present studies showed an overall $25 \%$ induction $(p<0.005)$ across the time course. In the apoptosis pathway, the current studies confirm mild induction of the NFkB inhibitor (Nfkbib, 17\% increase, $p<0.05$ ), caspase 1 (Casp1, 21\% increase, $p=0.005$ ) and the p53 tumor suppressor (Trp53, 17\% increase, $\mathrm{p}<0.05)$. Likewise, there was modest reduction in lamin B2 RNA levels (Lmnb2, $33 \%$ decrease, $\mathrm{p}<0.05$ ). Thus, while quite different models, and transcriptome methods, there is some agreement on the types of changes observed after diclofenac treatment.

Likewise, Sass et al. [21], conducted an extensive meta-analysis of the transcriptomic changes associated with different injuries to several organ systems (heart, liver, skin, bone, and spinal cord) in 3 different species (rat, mouse, and human). Their aggregated results in the form of gene ontologies affected over time during normal wound repair was compared to a similar analysis of the present data using Tr14-treated wound, and the 


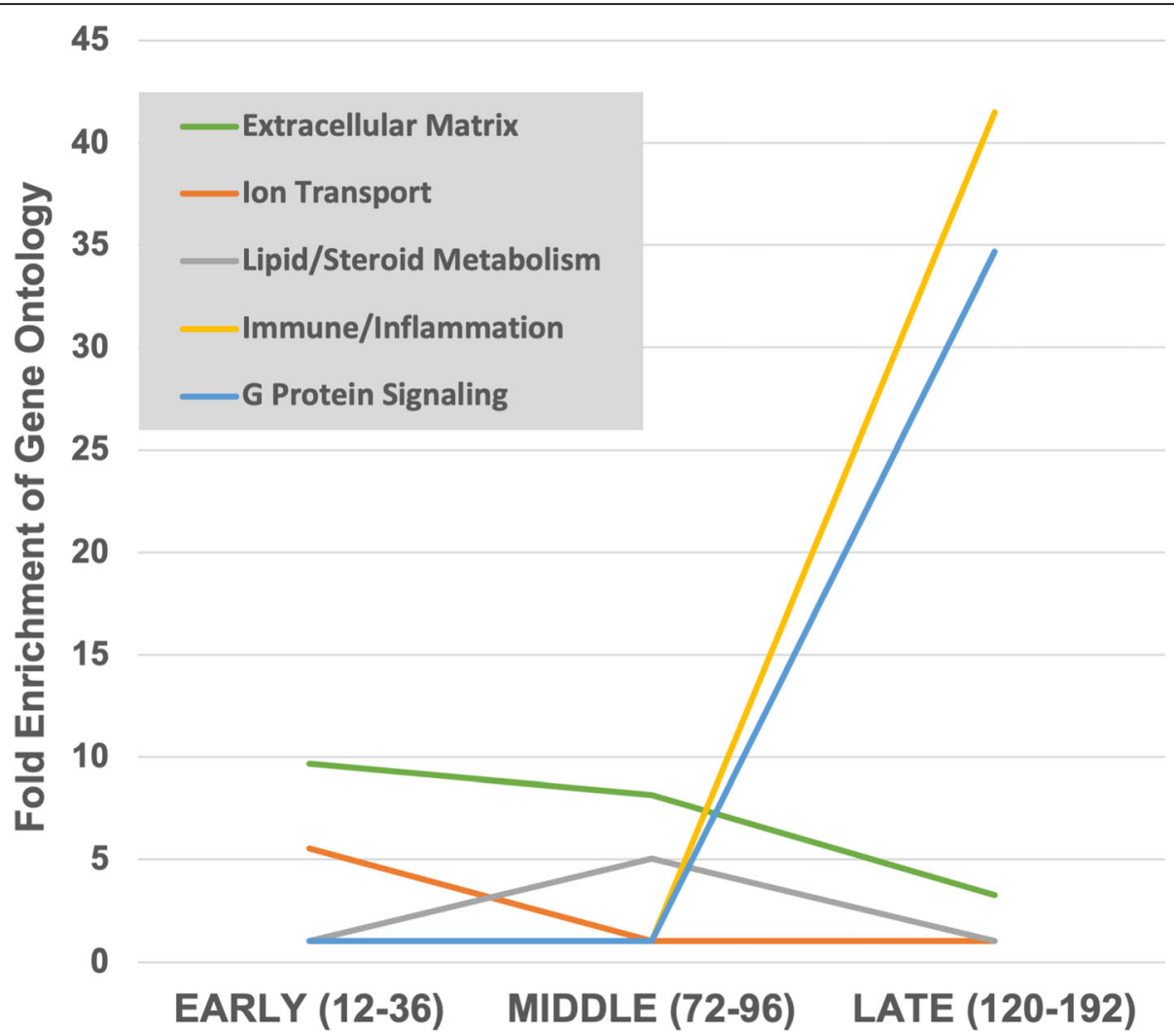

Fig. 4 Gene Set Enrichment Analysis (GSEA) of Tr14-modulated transcripts. GSEA of transcripts altered by Tr14 were manually curated into larger 'SuperClusters' based on their logical association in biological functions. Tr14 DEGs at each time point were analyzed by GSEA via NCBI DAVID, and then the enriched Gene Ontologies were filtered for false discovery rates (FDR) $<0.05$, and manually organized into the functional SuperClusters shown with a computed geometric mean fold change for $\operatorname{Tr} 14$ relative to its control

results are shown in Fig. 8. In general, there is excellent correspondence between the data sets, suggesting that prior microarray studies of normal wound repair identifies the same gene ontologies as are regulated by $\operatorname{Tr} 14$ in the current RNAseq studies.

\section{Discussion}

\section{Transcriptome analysis of murine wound healing}

The physiological process of wound healing provides an informative and comprehensive model for approaching the complexity of the tissue pathologies frequently involved in chronic diseases. In many ways, tissues affected by chronic diseases display physiological processes similar to those involved in wound healing, including the potential for inflammation, fibrosis, and scarring. The present studies examine the changes in genome-wide RNA expression patterns resulting from both phytochemical and NSAID therapeutics in the context of a complex physiological wound repair process. This study includes a dataset of over 4 billion sequence reads covering 250 animals, 4 conditions, and 8 time-points, making it a valuable ongoing resource for defining the wound repair process.

\section{Pathways involved in wound repair}

The initial GO enrichment analysis of this data set indicated that Tr14 treatment results in extensive gene expression changes during wound healing, including well known pathways such as TGF- $\beta$, cytokine signaling, inflammation, collagen, and enzymes of the extracellular matrix [3]. Interestingly, Tr14-treated mice revealed broad and statistically significant changes in two Gene Ontology groups of great importance to wound healing: Cell Differentiation and Cell Mobility and Migration. These signals may indicate effects upon resident fibroblasts and infiltrating immune cells, which could easily have been overlooked in simpler experimental models, or with methods that are not sensitive enough to detect RNA changes in smaller subsets of cells.

A systems-level analysis of these pathways affected by $\operatorname{Tr} 14$ and diclofenac suggested that there were relevant differences in the COX/LOX pathway, which were further explored in the present analysis. While it is common to divide eicosanoid metabolism into the COX and LOX pathways, there is considerable interplay between them, most notably in their shared use of the upstream substrates such as arachidonate acid as shown in Fig. 5. 


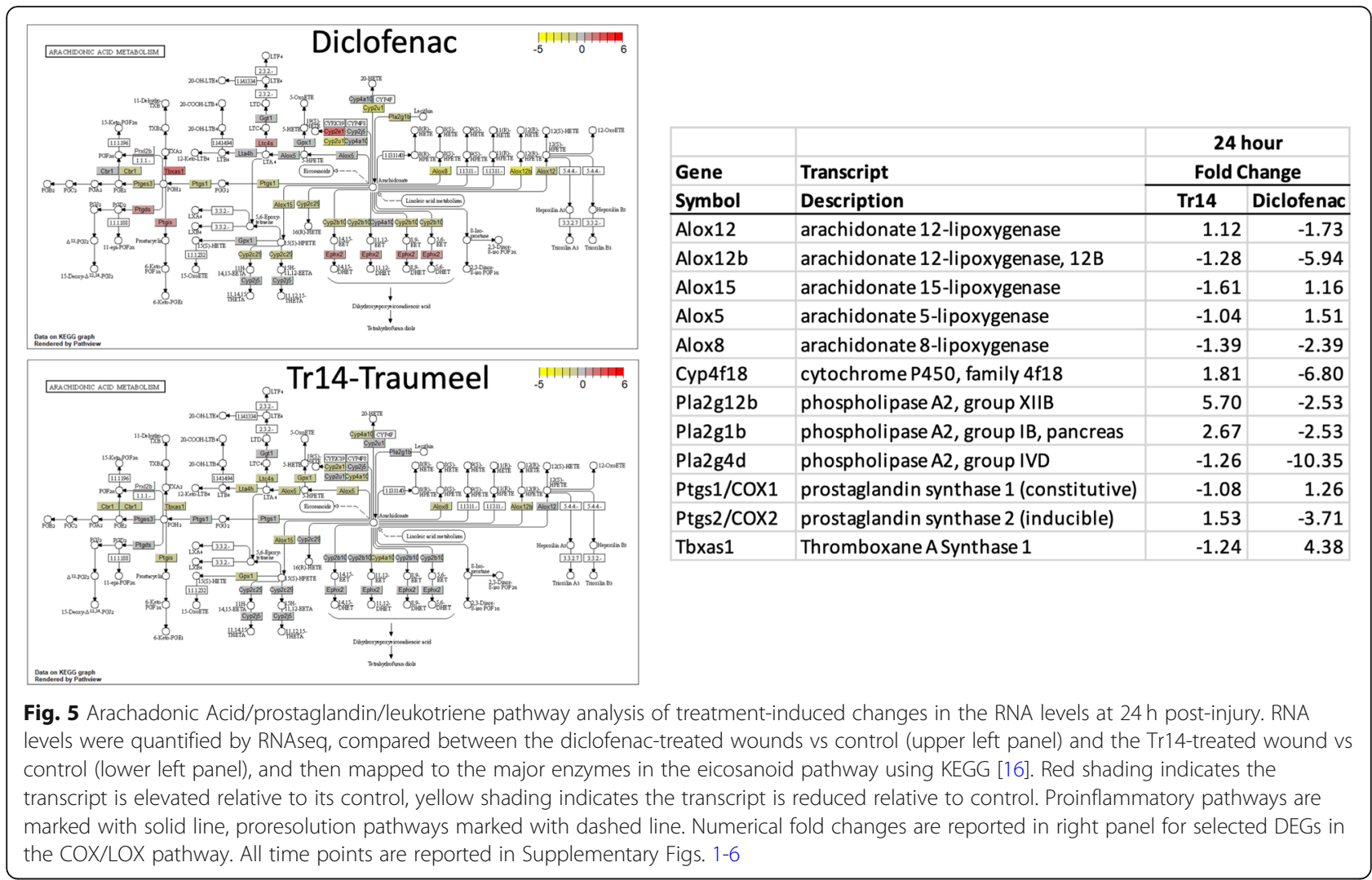

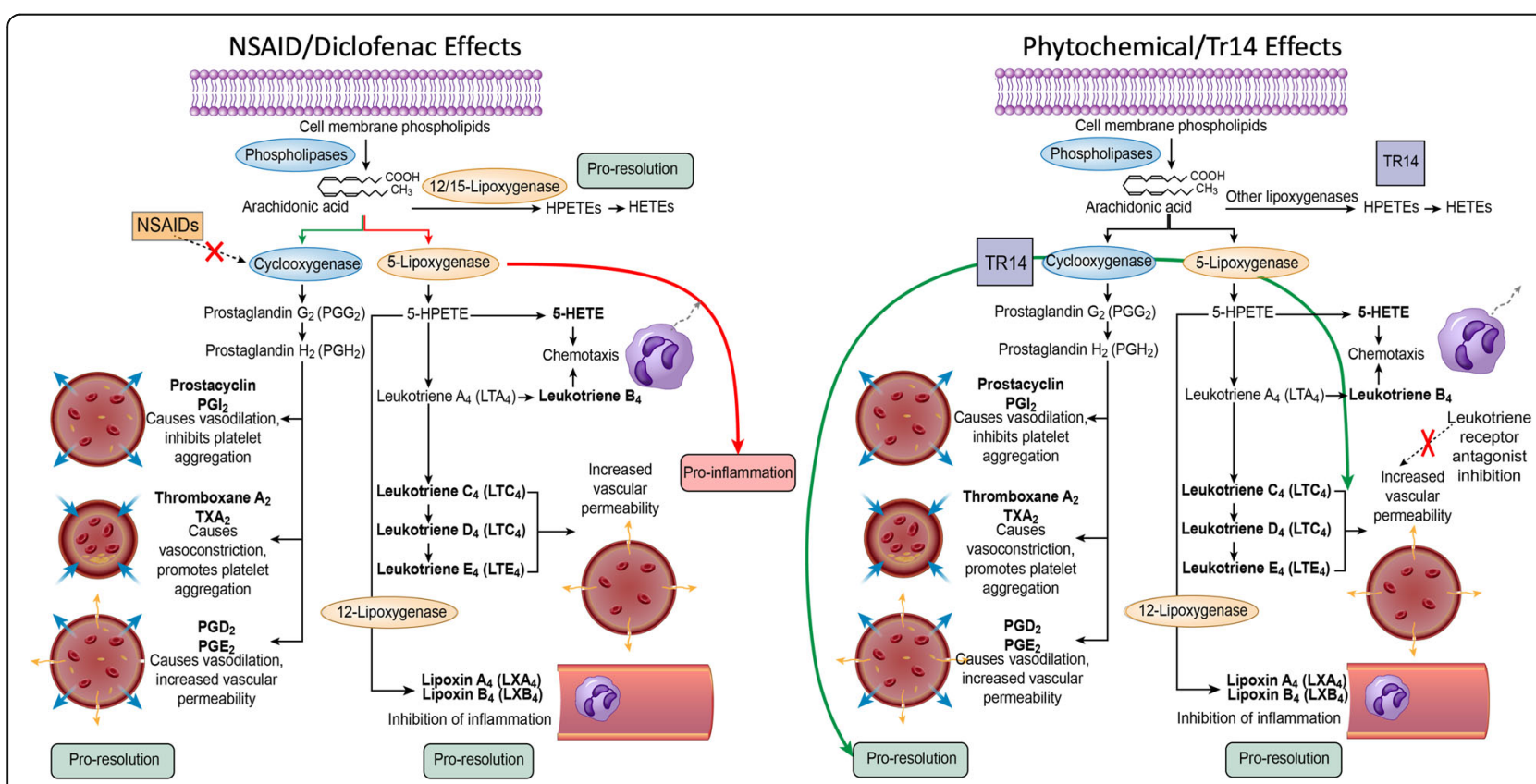

Fig. 6 Diclofenac and Tr14 effects in relation to biological pathways of tissue homeostasis and repair. The physiological effects of NSAIDs, such as diclofenac, are shown schematically in the left panel, compared to the putative actions of Tr14 in the right panel. NSAIDS have direct inhibitory on the cyclooxygenase enzymes, which alters numerous downstream eicosanoid actions on vasoconstriction/vasodilation, coagulation, chemotaxis, and inflammation/resolution. Tr14 does not directly inhibit COX enzymes, allowing a more natural wound repair process, but it does alter the mRNA levels for downstream enzymes in the pathway that might favor inflammation resolution 
Table 1 Immune cell markers modulated by Tr14

\begin{tabular}{llllll}
\hline Fold change & Adjusted $P$-value & Name & Description & Cell type & Effect/Pathway \\
\hline 1.67 & $3.31 \mathrm{E}-08$ & Cald1 & Caldesmon 1 & Macrophage & M2 mac infiltration \\
154.26 & $3.68 \mathrm{E}-04$ & Defb4 & Defensin beta 4 & Neutrophil & innate immunity \\
1.28 & $3.37 \mathrm{E}-06$ & Dlg1 & Discs Large MAGUK Scaffold 1 & T/B/Dendritic & antigen receptor \\
7.98 & $3.37 \mathrm{E}-02$ & Dusp14 & Dual Spec. Phosphatase 14 & T cell & neg reg T cells \\
17.73 & $6.54 \mathrm{E}-04$ & Fbp1 & Fructose-Bisphosphatase 1 & T cell & Nrf2 pathway \\
3.32 & $1.18 \mathrm{E}-14$ & Foxp3 & Forkhead Box P3 & T cell/Treg & consensus marker \\
4.13 & G.67E-01 & Gata3 & GATA Binding Protein 3 & T cell/Treg & FoxP3 system \\
1.83 & $2.31 \mathrm{E}-02$ & Ly6a & Lymphocyte antigen 6A & Lymphocyte & consensus marker \\
2.20 & $3.49 \mathrm{E}-02$ & Ly86 & Lymphocyte antigen 86 & Lymphocyte & consensus marker \\
1.72 & $3.13 \mathrm{E}-02$ & Mef2C & Myocyte Enhancer Factor 2C & Lym/Myocyte & transcription factor \\
2.94 & $5.72 \mathrm{E}-18$ & Sla2 & Src Like Adaptor 2 & T cell & TCR signaling \\
\hline
\end{tabular}

Clinically, it is widely held that the COX pathway produces 'beneficial' prostaglandins, such as prostacyclin, which has potent vasodilatory and antiplatelet effects, but also 'inflammatory' thromboxanes, such as TXA2, which is vasoconstrictive, platelet aggregating, and pain mediating (Fig. 6). The products of the LOX pathway are principally thought to mediate inflammation, bronchoconstriction, and pain, and thus selective inhibitors of the LOX pathway have been tested in conditions such as asthma and allergies [22].

\section{The COX pathway}

It is well established that injury-induced increases in COX2 mRNA levels are due in large part to NFkBdependent transcriptional activity [23]. In diclofenactreated wounds, the COX2 induction is blunted, likely because downstream products, especially PGE2, have been inhibited, and cannot contribute positive feedback to COX2 transcription [24, 25]. Conversely, Tr14 allowed normal induction of the COX2 enzyme, which may have important implications for downstream products, such as the resolvins.

\section{The LOX pathway}

The leukotriene pathway has diverse effects on inflammation and repair, and RNA levels of the enzymes have established relationships to human disease. LTA4 hydrolase mRNA is elevated in conditions such as glomerular inflammation, where immunocytochemistry confirms elevation of the protein product during disease progression [26]. The LTA4 hydrolase promoter contains both positive and negative regulatory elements, but the specific transcription factors have not been identified, although both Nrf2 (NFE2) and Maf sites are present [27]. Likewise, GGT1 has a proximal $\mathrm{Nfe} 2$ site, and the MGST1 promoter has a known response element for oxidative stress and contains an antioxidant response element/electrophile response element (ARE/EpRE) site
- 500 to the start site [28]. LTA4H is potentially a direct target for natural product-derived inhibitors [29]. There is suggestive evidence that plant quinones could directly block 5-LOX (ALOX5) enzyme activity, thereby blocking LTA4 and LTB4 synthesis [30], but it is not apparent how that direct inhibitory effect would affect the multiple ALOX transcripts modulated by Tr14.

\section{The Nrf2 system as a candidate mediator of phytochemical actions}

Several members of the leukotriene pathway enzymes that were altered by Tr14, such as MGST3 and Fbp1 (Table 1), contain antioxidant response elements (ARE) that confer regulation by the transcription factor Nrf2 (NFE2L2) [28, 31, 32]. Leukotriene synthetic enzymes, such as MGST3 [33] and GGT1 [34], have been identified as Nrf2 target genes, but GGT1 is also responsive to TNF-A-induced NFkB and Sp1 [35]. Nrf2 is known to control multiple elements in the eicosanoid synthetic pathway, typically via the ARE, as in the case of thromboxane A2 synthase gene activation [36] and the prostaglandin reductase Ptgr1 [37]. Interestingly, early induction of Nrf2 by one of the rhomboid transcription factors has been shown to mediate rapid cutaneous wound healing [38].

\section{Phytochemicals and the Nrf2 pathway}

Plant phytoestrogens and dietary polyphenols are known to regulate the Nrf2/Keap1 interaction in a manner that favors Nrf2 translocation to the nucleus, and Nrf2dependent transcription of target genes [39, 40]. Likewise, the inhibition of neuroinflammation by nut bioflavonoids has been attributed to the induction of the Nrf2/ARE antioxidant system [41]. Interestingly, the anti-inflammatory mechanism of the marine natural product, honaucin $\mathrm{A}$, has been attributed to activation of the Nrf2/Keap1 system via direct covalent modification of the sulfhydryl residues in Keap1 [42]. Likewise, plant 


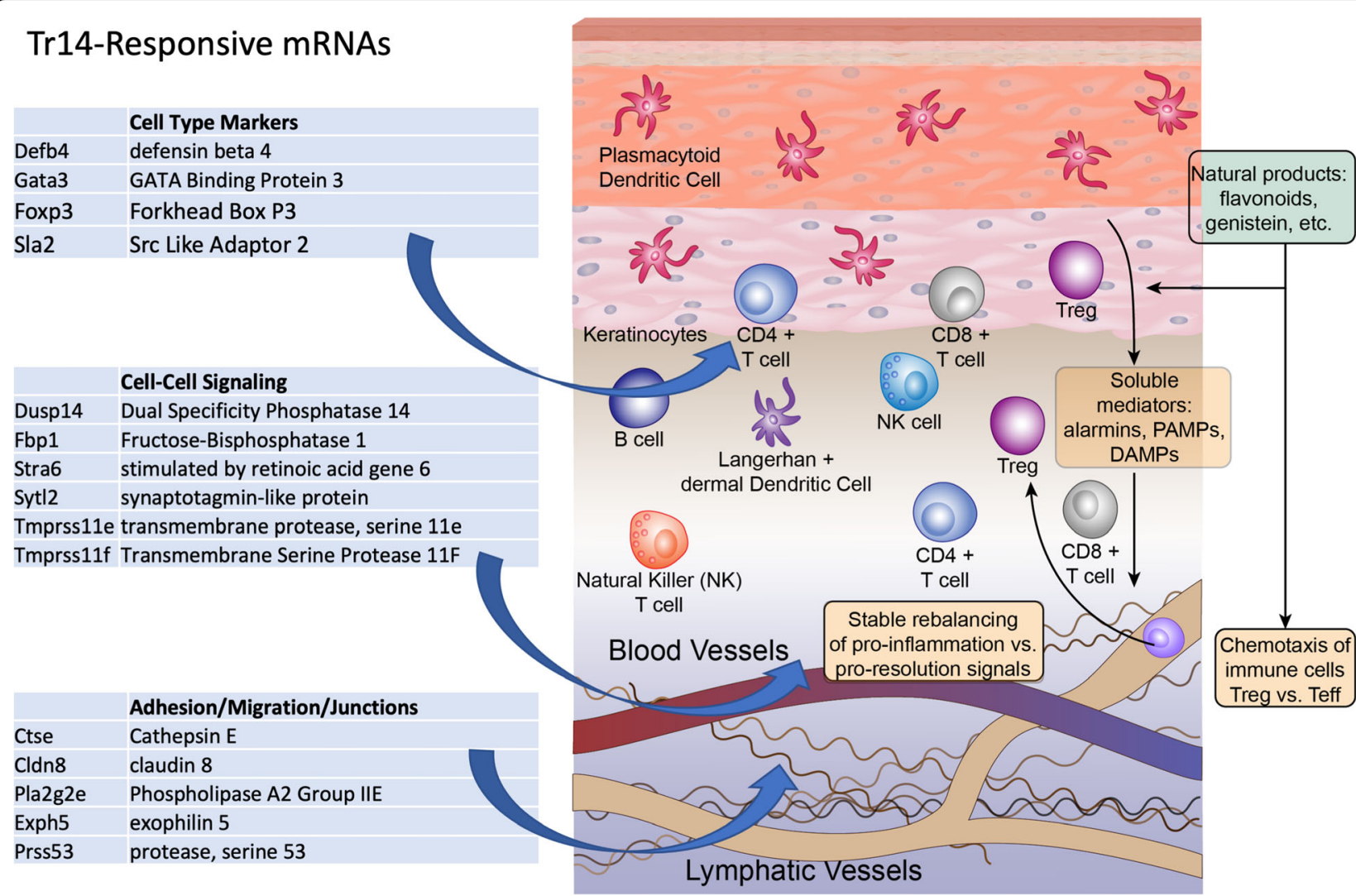

Fig. 7 Specific transcripts strongly modulated by Tr14 after injury. Differentially expressed genes (DEGs) modulated by Tr14 are organized as examples of transcripts that would be related to particular cell types present in the wound (i.e. FoxP3), and by transcripts that would modulate Cell-Cell Signaling of those cells (i.e. Dusp14), and their adhesion/migration junctions (i.e. Claudin 8)

phenylpropanoid glycosides have been shown to modulate Nrf2-dependent heme oxygenase 1 (Hmox1, HO1) transcription via regulating the balance of $\mathrm{Nrf} 2$ and Bach1 in human keratinocytes [43].

\section{The NFkB pathway}

In addition to the Nrf2 pathway, one must consider the possibility that the NFkB pathway is altered by the phytochemical treatments. Certain plant-derived isoflavanones, such as sappanone $A$, exert anti-inflammatory effects through both the Nrf2 and NF-kB pathways [44]. Many of the pathway members, such as MGST3 are modulated by both Nrf2 and NFkB [35], which complicates the problem of dissecting the precise transcription factors involved.

\section{A "Phytocellular" theory: phytochemicals as modulators of immune cell recruitment}

In addition to the direct pharmacological effects of phytochemicals on the transcriptional pathways of viable cells that remain in a wound, it is potentially important to consider whether phytochemicals could alter the types of cells that respond to the injury. This was suggested by relatively large changes in several transcripts that had known relationships to particular immune cell types, especially $\mathrm{T}$ cells and the Treg subset. As summarized in Fig. 7, phytochemicals include biologically active compounds, such as polyphenols, retinoids, flavonoids, genistein, and many others, that have documented effect on the recruitment and activity of immune cells $[45,46]$. In addition to a direct effect on the activity of the infiltrating immune cells, it is essential to consider that these same agents can alter the types of cytokines that are produced by the surviving resident cells in the wound, and alter their production of chemotactic agents. As shown schematically in Fig. 7, the healing wound must be considered in the context of an interplay between a range of cell types that includes keratinocytes, fibroblasts, dermal plasmacytoid dendritic cells, mast cells, neutrophils, B cells, $\mathrm{T}$ cells, especially gamma/delta and Treg, and natural killer (NK) cells (see [47] for review).

There is extensive data to support the concept that this cellular interplay is inseparable from the inflammatory and resolving chemical signals. Broadly, pro- 


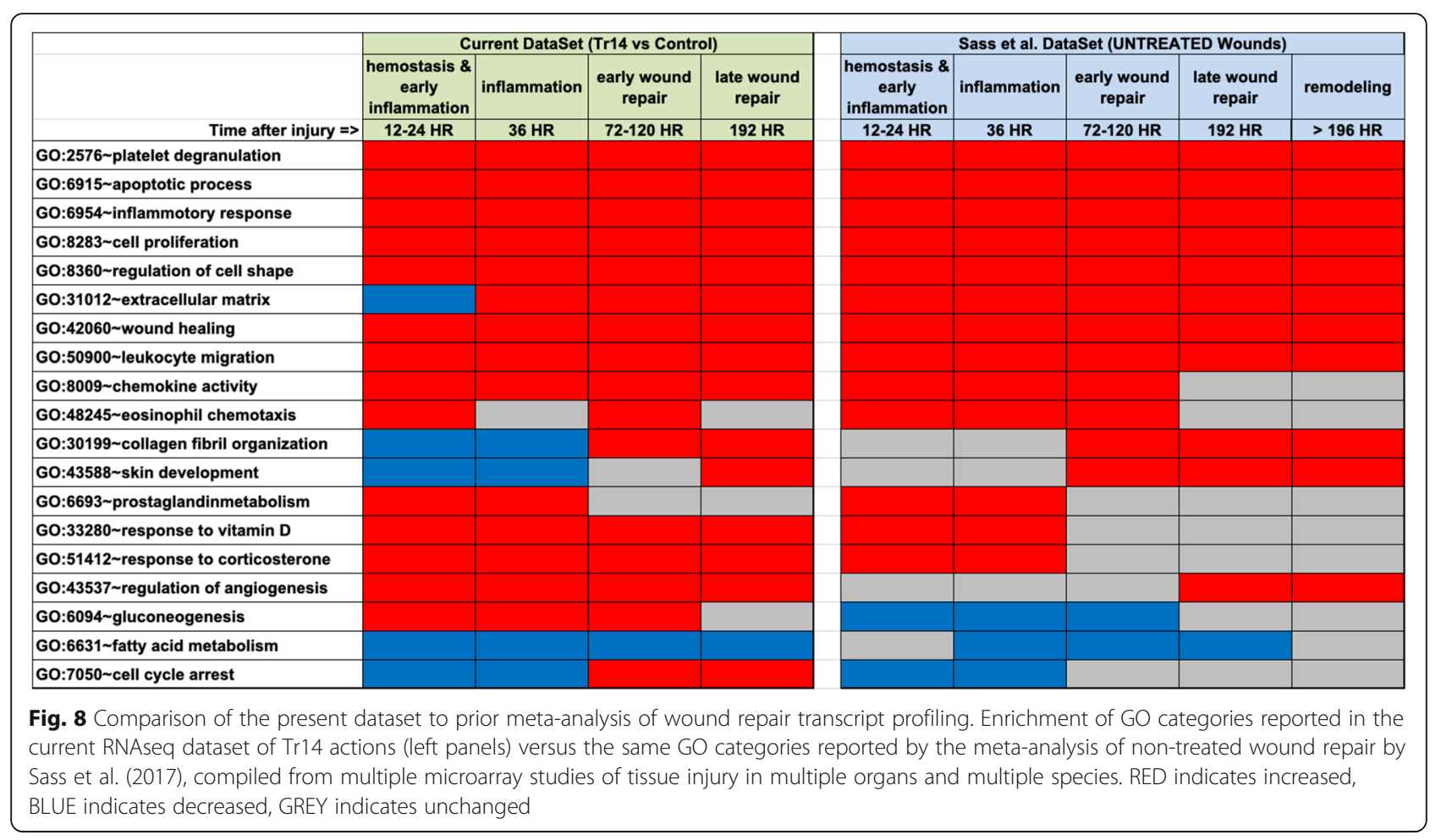

inflammatory components of wound repair must be tempered by pro-resolution factors, or the result can be a range of defects that ranges from chronic wounds, autoimmunity, hypertrophic scarring and keloid formation [48]. If, as the current data suggests, phytochemicals alter the type of cells that accumulate in the wound during repair, then there is a plausible explanation for their observed beneficial effects. In this 'phytocellular' framework, it is interesting to speculate that if $\operatorname{Tr} 14$ were to increase the timely infiltration of Treg cells, this could limit the pro-inflammatory effects of tissue damage. Future studies will require detailed RNA in situ hybridization and immunochemistry studies at selected time points to evaluate this hypothesis.

\section{Conclusions}

- The biological effects of Tr14, a multicomponent drug, are largely different than diclofenac, and impact different subsystems in the COX/LOX pathways during wound repair.

- Diclofenac, but not Tr14, inhibits COX-2 mRNA induction by blocking downstream PGE2 production.

- Tr14, but not diclofenac, reduces mRNA levels in the leukotriene synthetic pathway, possibly by activating the Nrf2/KEAP2 pathway.

- Tr14 causes a transcriptomic signature that is consistent with alterations in the types of cells that are present in the wound, and appears most consistent with elevated Treg composition in Tr14treated wounds.

\section{Methods}

\section{Wound healing model}

The overall experimental workflow and data analysis is shown in Fig. 1. Animal care and use was approved by the Nantong University Animal Care Committee and complied with all relevant guidelines for humane use. The ICR strain of mice in the age range of 4-6 weeks, approximately $20 \mathrm{~g}$ each, was used for the wound healing studies. The skin abrasion model is based closely on prior published work that documents the histological changes over time and in response to laser stimulation [49]. Under sedation (ketamine $100 \mathrm{mg} / \mathrm{kg}$, xylazine 10 $\mathrm{mg} / \mathrm{kg}$ IP), the mouse dorsal/scapular region was shaved and then a $1 \mathrm{~cm}^{2}$ area was wounded by rotary abrasion. The abrasion results in a partial-thickness wound with removal of the epidermis and part of the dermis, with a mild superficial bleeding response that quickly scabs, does not require analgesia post-operatively. In prior publications, the temporal association between the histological/cellular stage of repair and gene expression is reported in this same model [3].

To optimize its effect, Tr14 was introduced as subcutaneous injections of $0.1 \mathrm{ml}(9.5 \mathrm{ml} / \mathrm{ml})$ in the region around the wound, without sedation, with twice daily topical treatment $(34 \mathrm{mg} / \mathrm{ml})$ to the wound (TTI group) and compared to mice treated with saline injections (SI). 
Diclofenac was applied at clinically relevant doses of 2 $\mathrm{mg} / \mathrm{ml}$. The diclofenac group (DT) and its control group (PT) did not receive sc injections. A standardized $1 \mathrm{~cm}^{2}$ piece of affected skin was recovered by sacrifice, via ketamine/xylazine overdose and cervical dislocation, at specific times: 0, 12, 24, 36, 72, 96, 120, and $192 \mathrm{~h}$ after injury. Tissue was stored in RNAlater at $-80^{\circ} \mathrm{C}$ until RNA was isolated as described below. Each time point of each treatment or control group included 7 mice.

\section{Isolation of Total RNA from tissues}

Total RNA from tissue samples and cell lines was extracted using TRIzol (Invitrogen) using the manufacturer's protocol. The sample was homogenized with a Tissue Tearer rotary blade device while suspended within an appropriate volume (10x sample volume) of TRIzol [50]. After $10 \mathrm{~min}$ at room temperature, the samples were centrifuged to remove insoluble material and the supernatant transferred to a fresh tube. Chloroform (0.2X TRIzol volume) was then added to the contents of the new tube and vigorously vortexed. Samples were then centrifuged for $15 \mathrm{~min}$ at $12,000 \mathrm{x} \mathrm{g}$ at $4{ }^{\circ} \mathrm{C}$. The upper aqueous phase, which contains RNA, was then carefully transferred to a new tube. The addition of isopropyl alcohol (0.5X TRIzol volume) to the samples followed by a 10 -min room temperature incubation and a subsequent 10 -min centrifugation at $12,000 \mathrm{x}$ g at $4{ }^{\circ} \mathrm{C}$ precipitated the RNA into a gel-like pellet at the bottom of the tube. After the removal of the supernatant, the pellet was washed twice in $1 \mathrm{ml}$ of ice-cold $75 \%$ ethanol. The resulting pellet of RNA was then allowed to dry for $10 \mathrm{~min}$ and then resuspended in DEPC-treated water. The quantity of the resulting RNA was measured by the absorbance at $260 \mathrm{~nm}$, and the relative contamination with proteins was measured by the ratio of optical density (OD) at $260 / 280$ on a NanoDrop instrument (Thermo Scientific). A ratio greater than 1.8 is desirable.

\section{Depletion of genomic DNA (gDNA) and ribosomal RNA (rRNA)}

In addition to messenger RNA (mRNA) and non-coding RNA (ncRNA), total RNA extracted from tissue samples contain large quantities of ribosomal RNA (rRNA), transfer RNA (tRNA) and residual amounts of genomic DNA (gDNA). The sequencing reads are used most efficiently if the rRNA and gDNA is depleted prior to sequencing.

\section{DNAse treatment}

Total nucleic acid from the TriZol step is first DNasetreated to remove any residual DNA. Approximately $40 \mu \mathrm{g}$ of total RNA (with $20 \mu \mathrm{l} 10 \mathrm{x}$ buffer, $4 \mu \mathrm{l}$ DNase 1 (Ambion), $2 \mu$ l Rnase-out (Invitrogen) in a total volume of $200 \mathrm{ul}$ ) is incubated for $30 \mathrm{~min}$ at $37^{\circ} \mathrm{C}$. Samples are then cleaned using the RNeasy MinElute cleanup kit (Qiagen) following manufacturer's protocol. In brief, $700 \mu \mathrm{l}$ Buffer RLT and $500 \mu \mathrm{l} 100 \%$ ethanol are added to the sample which is then added to a MinElute spin column. The columns are washed with $500 \mu$ l Buffer RPE followed by $500 \mu \mathrm{l} 80 \%$ Ethanol. After an additional 2min centrifugation to remove any residual ethanol, the sample is eluted in $14 \mu \mathrm{l}$ DEPC treated water. The quality of RNA was then assessed using an Agilent 2100 Bioanalyzer and the RNA 6000 Nano Kit (Agilent) using manufacturer's protocol and the sample was quantified using a Nanodrop, as described above.

\section{rRNA depletion}

Samples were depleted of ribosomal RNA through the use of the RiboMinus Eukaryote Kit for RNA-Seq (Invitrogen) following the manufacturer's protocol. In brief, $10 \mu \mathrm{g}$ of sample RNA (in a total of $10 \mathrm{ul}$ ) were incubated with $10 \mu \mathrm{l}$ RiboMinus probe and $100 \mu \mathrm{l}$ Hybridization Buffer for $5 \mathrm{~min}$ at $75^{\circ} \mathrm{C}$ then allowed to slowly cool to $37^{\circ} \mathrm{C}$ over the course of $30 \mathrm{~min}$. The RiboMinus probe contains $5^{\prime}$ biotinylated Locked Nucleic Acid probes that are complementary to conserved eukaryotic 5S, $5.8 \mathrm{~S}, 18 \mathrm{~S}$ and $28 \mathrm{~S}$ ribosomal sequences. Streptavidincoated RiboMinus Magnetic Beads were washed once in water, resuspended in hybridization buffer, separated into two aliquots and kept at $37^{\circ} \mathrm{C}$ until use. Sample was added to the prepared beads and incubated at $37^{\circ} \mathrm{C}$ for 15 min with occasional agitation. The beads were placed on a magnetic separator and the supernatant containing the enriched RNA was removed and added to the second aliquot of beads and the protocol repeated. The final supernatant $(\sim 320 \mathrm{ul})$ was precipitated using $1 \mu \mathrm{l}$ glycogen (Invitrogen), $30 \mu \mathrm{l} 3 \mathrm{M}$ sodium acetate and $75 \mu \mathrm{l}$ $100 \%$ ethanol. The mixture was incubated at $-80^{\circ} \mathrm{C}$ for $1 \mathrm{~h}$ and then centrifuged for $15 \mathrm{~min}$ at $12000 \mathrm{x} \mathrm{g}$ at $4{ }^{\circ} \mathrm{C}$. The pellet was washed twice with cold $75 \%$ ethanol, air dried for $5 \mathrm{~min}$ and then resuspended in $30 \mu \mathrm{l} \mathrm{DEPC}$ treated water. Quality of RNA was then re-assessed using an Agilent 2100 Bioanalyzer and their RNA 6000 Pico Kit (Agilent) using manufacturer's protocol and the sample was quantified using a Nanodrop as per above.

\section{Transcriptome sequencing sample preparation}

A published description of the single-molecule sequencing methodology for transcriptome quantification is described by Lipson et al. [51]. A brief summary follows.

\section{Complementary DNA (cDNA) synthesis}

Complementary DNA (cDNA) from rRNA-depleted RNA was prepared using the Superscript III cDNA synthesis kit (Invitrogen). In brief, $200 \mathrm{ng}$ of RNA was resuspended in $17 \mu \mathrm{l}$ nuclease-free water and heated at $95{ }^{\circ} \mathrm{C}$ for $5 \mathrm{~min}$ to fragment the RNA and thus improve 
the eventual evenness of coverage. Random hexamers $(10 \mu \mathrm{l}$ of $50 \mathrm{ng} / \mathrm{ul})$ and dNTPs $(2 \mu \mathrm{l}$ of $10 \mathrm{mM}$ mix $)$ were added to the RNA and the mixture was heated to $65^{\circ} \mathrm{C}$ for $5 \mathrm{~min}$, and then placed on ice for $2 \mathrm{~min}$. A mixture of 10X buffer $(5 \mu \mathrm{l}), 0.1 \mathrm{M}$ DTT $(1 \mu \mathrm{l})$ and $25 \mathrm{mM}$ $\mathrm{MgCl} 2(10 \mathrm{ul}$ ) was added to the tube and the mixture was incubated at $15^{\circ} \mathrm{C}$ for $20 \mathrm{~min}$. A mixture of RnaseOut $(2.5 \mathrm{ul})$ and SSIII reverse transcriptase $(2.5 \mu \mathrm{l})$ was then added to the tube and the sample incubated $\left(25^{\circ} \mathrm{C}\right.$ $10 \mathrm{~min}, 40^{\circ} \mathrm{C} 40 \mathrm{~min}, 55^{\circ} \mathrm{C} 50 \mathrm{~min}, 85^{\circ} \mathrm{C} 5 \mathrm{~min}, 4{ }^{\circ} \mathrm{C}$ hold). The RNA remaining in the sample was then degraded by the addition of $1 \mu \mathrm{l}$ RNase $\mathrm{H}$ and $1 \mu \mathrm{l}$ RNase If (New England Biolabs, M0243L). The resulting cDNA was then purified by the serial use of two Performa Gel Filtration Columns (EdgeBio, 42,453). The concentration of the resulting cDNA was then quantified using the Nanodrop as previously described [51].

\section{Poly a tailing}

This step adds 3' poly-A tails to the cDNA, which facilitates hybridization to the flow cell for sequencing. Using $100 \mathrm{ng}$ of the prepared cDNA in $28 \mu \mathrm{l}$ water, $5 \mu \mathrm{l}$ Helicos PolyA Control Oligos are added and the mixture incubated at $95^{\circ} \mathrm{C}$ for $5 \mathrm{~min}$ followed by a 2-min ice incubation. A mixture of $\mathrm{CoCl}(5 \mu \mathrm{l}), 10 \mathrm{X}$ TdT buffer $(5 \mu \mathrm{l})$ Helicos PolyA tailing dATP $(5 \mu \mathrm{l})$ and Terminal Transferase $(2 \mu \mathrm{l})$ was then added to the sample with thorough mixing. The samples were then incubated $\left(42{ }^{\circ} \mathrm{C}, 60 \mathrm{~min}\right.$, $70{ }^{\circ} \mathrm{C} 10 \mathrm{~min}, 4^{\circ} \mathrm{C}$ hold). The success of the polyA tailing was determined through the use of a 3730 DNA Analyzer (Applied Biosystems, 3730S) following manufacturer's procedures. In brief, $1 \mu \mathrm{l}$ of sample was added to $8.9 \mu \mathrm{l}$ formamide and $0.1 \mu \mathrm{l}$ GeneScan-120 LIZ Size Standard (Applied Biosystems, 4,324,287), and the samples were denatured at $95{ }^{\circ} \mathrm{C}$ for 2.5 min then cooled on ice and run on the machine [51].

\section{3' blocking and tailing oligo removal}

After addition of poly A tail, the 3' tail of the cDNA sample is then blocked, and the tailing oligo is removed. The sample is denatured at $95^{\circ} \mathrm{C}$ for 5 min followed by a 2 -min incubation on ice. $0.4 \mu \mathrm{l}$ biotinylated ddATP (Perkin Elmer) and $2 \mu \mathrm{l}$ Terminal Transferase (New England Biolabs) are added and the samples incubated $\left(37^{\circ} \mathrm{C} 60 \mathrm{~min}, 70^{\circ} \mathrm{C} 10 \mathrm{~min}\right)$. The sample is then digested with $1 \mu \mathrm{l}$ USER enzyme (New England Biolabs) at $37^{\circ} \mathrm{C}$ for $30 \mathrm{~min}$ [51].

\section{Sample cleanup}

The samples obtained from prior steps are then cleaned up using AMPure Beads (Beckman Coulter). The beads are allowed to equilibrate at room temperature for 30 min before use. Each probe sample is then brought up to a total volume of $60 \mu \mathrm{l}$ and mixed with $72 \mu \mathrm{l}$ AMPure beads and incubated at room temperature for $30 \mathrm{~min}$ with occasional mixing. Using a magnetic stand, the beads are then collected, and the beads are washed twice with $500 \mu \mathrm{l} 70 \%$ ethanol. After the final wash the beads are allowed to dry for 5-10 min to remove all traces of ethanol. The beads are then suspended twice in $20 \mu \mathrm{l} \mathrm{TE}$ buffer and the supernatant containing the probes removed to a clean tube each time after 5 min on the magnetic stand. Samples are then precisely quantified using the OptiHyb procedure. In brief, oligo-dT coated mRNA Catcher Plus plates (Invitrogen) are used to collect replicates of $2 \mu \mathrm{l}$ of sample in $48 \mu$ l hybridization buffer $(1 \mathrm{x}$ SSC, $0.5 \%$ SDS). After a one-hour incubation at $37^{\circ} \mathrm{C}$ the plates are washed $3 \mathrm{x}$ in Wash Buffer B (150 mM HEPES, 0.1\% SDS, 1X SSC) then blocked for $15 \mathrm{~min}$ at room temperature in Blocking Buffer (0.1 M Tris pH 7.6, $0.15 \mathrm{M} \mathrm{NaCl}, 0.5 \%$ Casein). Streptavidin-HRP conjugate (Thermo Fisher) is added to Block buffer and the plates are incubated in that mix for $1 \mathrm{~h}$ at room temperature. After 3 washes in Wash Buffer $2(0.1 \mathrm{M}$ Tris pH 7.6, $0.15 \mathrm{M} \mathrm{NaCl}, 0.05 \% \mathrm{Tw} 20)$ the plates are dried and then incubated for $30 \mathrm{~min}$ in the dark with TMB Chromogenic Substrate (Sigma). Upon addition of $1 \mathrm{~N} \mathrm{HCl}$ the samples are then measured at $450 \mathrm{~nm}$ on an EnVision Multilabel Reader (PerkinElmer). Concentrations were determined by comparison to a control dilution on the same plate.

\section{Sample loading}

After the measurements, the samples are loaded onto the flow cells. In brief, appropriate quantities of samples are diluted into hybridization buffer. The flow cells are then rehydrated for $3 \mathrm{~h}$ and brought to $55^{\circ} \mathrm{C}$. The flow cells are then equilibrated with loading buffer and then the samples are loaded and allowed to hybridize for $1 \mathrm{~h}$ to the flow cells, which are coated with oligo dT that hybridizes the polyA tails of the samples. The flow cells are then repeatedly washed to remove excess sample. A single fluorescent nucleotide is then added to each of the annealed probes on the flow cell so that, upon loading into the Heliscope, the location of each individual sample molecule can be determined. The flow cells are then loaded into the Heliscope and subsequent sequencing is automated [51].

\section{Sequencing operation and monitoring}

Once the flow cells are loaded onto the SeqLL SMS, sequencing chemistry begins. Fluorescently labeled nucleotides are added one at a time to the flow cells. These nucleotides bind to complementary bases on the cDNA strand, whose 3' Poly A tail is hybridized to the oligo dT probes in the flow cell. Unbound nucleotides are then washed away. Bound fluorescent nucleotides emit light under a laser beam, which is captured by a CCD camera. 
This determines which nucleotide is incorporated and the position in the template. The fluorescently labeled portion of the nucleotide is then cleaved off. The process is repeated for all four nucleotide bases and continued until a sequence read of desired read length is obtained. On average $35 \mathrm{nt}$. reads are generated with a throughput of 105 to 140 megabases per hour.

\section{Bioinformatics data analysis \\ Filtering and alignment}

Each channel produces an average of 45 million total reads, which are then filtered as previously described, using the Helisphere software ( $v$ 1.2.740) to remove low complexity sequences and sequencing artifacts [52]. Low complexity sequences, such as poly A, and short reads under 25 nucleotides are removed by this process. Reads were aligned to mouse genome mm10 combined with SILVA ribosomal RNA reference sequences (LSUr123, SSUr123). To avoid ambiguity, we selected uniquely aligned reads only. The number of reads spanned the exon intervals of known transcripts were calculated using a custom perl script. The sum of exonic reads counts for each transcript is treated as raw Digital Gene Expression (raw DGE). Out of 138,930 transcripts we selected only one per gene using the following criteria: a) one transcript with maximum exon lengths was selected for each gene, $b$ ) the transcripts with names started from "Gm" and "Rik" were removed. At the end of the pipeline 25,482 genes/transcripts remained. With mapping data as input, transcript expression levels are calculated and presented in units of RPK10M (reads per thousand (K) nucleotides length of transcript, per 10 million reads captured per sample.) Previous studies confirm that quantitative expression levels generated by this process meet or exceed quality levels of microarray data, as measured by RT-PCR validation [53].

\section{Differentially expressed genes (DEG)}

We calculate fold change and $p$-value (probability to get that or better fold change by chance) for each of 138,930 transcripts when comparing between two different conditions (i.e. diclofenac vs topical placebo). Fold change is $\log 2$ scaled. To normalize raw DGE counts and calculate $p$-values, the DEseq2 Bioconductor software package (version 1.22.2) was employed [54]. An over-dispersed Poisson model was used to account for both biological and technical variability. To calculate p-values the Likelihood ratio test (LRT) option was used. It allows to identify any genes that show change in expression across the different time points. Benjamini-Hochberg method was used to correct the $p$-values for multiple testing. DEGs in the comparison of Diclofenac versus it's control were defined through transcripts with adjusted p-value less than $10^{-6}$. To define DEGs of $\operatorname{Tr} 14$ versus control the adjusted p-value cutoff $10^{-3}$ was applied. The transcripts with names started from "Gm" and "Rik" were removed from DEGs list. In total 5615 transcripts (corresponding to 2218 genes) remained in the joint list of Diclofenac and Tr14 DEGs (Suppl. Table 1).

\section{Transcriptome data analysis}

Using data analysis generated above, several systemslevel analyses were performed. To understand the correlations and patterns among different elements of the transcriptome, DEGs are mapped to their respective biological pathways and Gene Ontology (GO) categories [55]. Changes enriched in individual pathways or ontologies are tested for their statistical significance. GO categories that have a number of hits greater than expected by chance with adjusted $\mathrm{p}$-value less than 0.05 are listed in the results. $P$-value is calculated using Hypergeometric model and adjusted for multiple testing using the Benjamini-Hochberg method.

\section{Supplementary Information}

The online version contains supplementary material available at https://doi. org/10.1186/s12864-021-08083-2.

Additional file 1: Supplementary Figs. 1-6. KEGG analysis of the COX/LOX pathway at multiple time points.

Additional file 2: Supplementary Table 1. Comprehensive list of DEGs responding to diclofenac and Tr14 over time.

\section{Acknowledgements}

The authors are deeply indebted to the vision of Dr. Georges St. Laurent III, who sadly passed during the completion of these studies.

\section{Authors' contributions}

The studies were conceived and designed by GSL3, TM, BS, and KC. JZ, IT, TJ, MT conducted the wound repair studies, sample harvest, RNA preparation, and/or RNA sequencing. MR, DS, MS, DA, KC, and TM conducted the bioinformatic analysis of the RNAseq, including DEG identification, interpretation, and analysis. The first draft manuscript was written by TM, GSL3, KC, MS, and BS with input from all of the authors. All authors reviewed all drafts and approved the final version of the manuscript for publication and agreed with its contents and submission.

\section{Funding}

The studies were funded jointly by Heel $\mathrm{GmbH}$ and the St. Laurent Institute.

Availability of data and materials

The data sets generated and analyzed during the current study are available in NCBI Sort Read Archive (SRA) as BioProject PRJNA726431, (https://trace. ncbi.nlm.nih.gov/Traces/study/?acc=PRJNA726431).

\section{Declarations}

Ethics approval and consent to participate

The ICR strain of mice in the age range of 4-6 weeks, approximately $20 \mathrm{~g}$ each, was used for the wound healing studies, under protocols approved by Nantong University Animal Care Committee (PR China). The studies were conducted in compliance with ARRIVE guidelines and in compliance with all applicable guidelines and regulations. 


\section{Competing interests}

TM has received speaker honoraria from Heel GmbH. TM, IT, and TJ have an equity interest in True Bearing Diagnostics, Inc., a privately held diagnostics company, but there is no real or perceived overlap with the present publication. All other authors declare there are no competing interests.

\section{Author details}

${ }^{1} T$ The St. Laurent Institute, Vancouver, WA, USA. ${ }^{2}$ SeqLL, Inc., Woburn, MA, USA. ${ }^{3}$ Department of Medicine, Division of Genomic Medicine, The George Washington University Medical Center, 2300 Eye St, Washington D.C 20037, USA. ${ }^{4}$ Heel GmbH, Baden-Baden, Germany. ${ }^{5}$ AcademGene, LLC, Novosibirsk, Russia. ${ }^{6}$ A.P. Ershov Institute of Informatics Systems, Novosibirsk, Russia.

Received: 16 April 2021 Accepted: 8 October 2021

Published online: 25 November 2021

\section{References}

1. Richardson RJ. Parallels between vertebrate cardiac and cutaneous wound healing and regeneration. NPJ Regen Med. 2018;3(1):21.

2. Dvorak HF. Tumors: wounds that do not heal. Similarities between tumor stroma generation and wound healing. N Engl J Med. 1986;315(26):1650-9. https://doi.org/10.1056/NEJM198612253152606.

3. St Laurent G 3rd, Seilheimer B, Tackett M, Zhou J, Shtokalo D, Vyatkin Y, et al. Deep sequencing transcriptome analysis of murine wound healing: effects of a multicomponent, multitarget natural product therapy-Tr14. Front Mol Biosci. 2017:4:57. https://doi.org/10.3389/fmolb.2017.00057.

4. Levy BD. Resolvins and protectins: natural pharmacophores for resolution biology. Prostaglandins Leukot Essent Fatty Acids. 2010;82(4-6):327-32. https://doi.org/10.1016/j.plefa.2010.02.003

5. Serhan CN. Discovery of specialized pro-resolving mediators marks the dawn of resolution physiology and pharmacology. Mol Asp Med. 2017;58:111. https://doi.org/10.1016/j.mam.2017.03.001.

6. Koeberle A, Werz O. Multi-target approach for natural products in inflammation. Drug Discov Today. 2014;19(12):1871-82. https://doi.org/10.1 016/j.drudis.2014.08.006.

7. Koeberle A, Werz O. Natural products as inhibitors of prostaglandin E2 and pro-inflammatory 5-lipoxygenase-derived lipid mediator biosynthesis. Biotechnol Adv. 2018;36(6):1709-23. https://doi.org/10.1016/j.biotechadv.201 8.02.010.

8. Khan H, Rengasamy KRR, Pervaiz A, Nabavi SM, Atanasov AG, Kamal MA. Plant-derived mPGES-1 inhibitors or suppressors: a new emerging trend in the search for small molecules to combat inflammation. Eur J Med Chem. 2018;153:2-28. https://doi.org/10.1016/j.ejmech.2017.12.059.

9. Porozov S, Cahalon L, Weiser M, Branski D, Lider O, Oberbaum M. Inhibition of IL-1 beta and TNF-alpha secretion from resting and activated human immunocytes by the homeopathic medication Traumeel S. Clin Dev Immunol. 2004;11(2):143-9. https://doi.org/10.1080/10446670410001722203.

10. Baldwin AL, Bell IR. Effect of noise on microvascular integrity in laboratory rats. J Am Assoc Lab Anim Sci. 2007;46(1):58-65.

11. Muders K, Pilat C, Deuster V, Frech T, Kruger K, Pons-Kuhnemann J, et al. Effects of Traumeel (Tr14) on exercise-induced muscle damage response in healthy subjects: a double-blind RCT. Mediat Inflamm. 2016;2016:1693918.

12. Muders K, Pilat C, Deuster V, Frech T, Kruger K, Pons-Kuhnemann J, et al. Effects of Traumeel ( $\operatorname{Tr} 14)$ on recovery and inflammatory immune response after repeated bouts of exercise: a double-blind RCT. Eur J Appl Physiol. 2017:117(3):591-605. https://doi.org/10.1007/s00421-017-3554-8.

13. Gonzalez de Vega C, Speed C, Wolfarth B, Gonzalez J. Traumeel vs. diclofenac for reducing pain and improving ankle mobility after acute ankle sprain: a multicentre, randomised, blinded, controlled and non-inferiority trial. Int J Clin Pract. 2013;67(10):979-89.

14. Gan TJ. Diclofenac: an update on its mechanism of action and safety profile. Curr Med Res Opin. 2010;26(7):1715-31. https://doi.org/10.1185/03007995.2 010.486301.

15. Chung H, Kim HJ, Jang KS, Kim M, Yang J, Kim JH, et al. Comprehensive analysis of differential gene expression profiles on diclofenac-induced acute mouse liver injury and recovery. Toxicol Lett. 2006;166(1):77-87. https://doi. org/10.1016/j.toxlet.2006.05.016.

16. Kanehisa M, Furumichi M, Sato Y, Ishiguro-Watanabe M, Tanabe M. KEGG: integrating viruses and cellular organisms. Nucleic Acids Res. 2021:49(D1): D545-51. https://doi.org/10.1093/nar/gkaa970.
17. Yang CY, Li JP, Chiu LL, Lan JL, Chen DY, Chuang HC, et al. Dual-specificity phosphatase 14 (DUSP14/MKP6) negatively regulates TCR signaling by inhibiting TAB1 activation. J Immunol. 2014;192(4):1547-57. https://doi.org/1 0.4049/jimmunol.1300989.

18. Wang HM, Wu C, Jiang YY, Wang WM, Jin HZ. Retinol and vitamin a metabolites accumulate through RBP4 and STRA6 changes in a psoriasis murine model. Nutr Metab (Lond). 2020;17(1):5. https://doi.org/10.1186/s12 986-019-0423-y.

19. He H, Bissonnette R, Wu J, Diaz A, Saint-Cyr Proulx E, Maari C, et al. Tape strips detect distinct immune and barrier profiles in atopic dermatitis and psoriasis. J Allergy Clin Immunol. 2021;147(1):199-212. https://doi.org/10.101 6/j.jaci.2020.05.048.

20. Yamamoto K, Miki $Y$, Sato $H$, Nishito $Y$, Gelb MH, Taketomi $Y$, et al. Expression and function of group IIE phospholipase A2 in mouse skin. J Biol Chem. 2016;291(30):15602-13. https://doi.org/10.1074/jbc.M116. 734657

21. Sass PA, Dabrowski M, Charzynska A, Sachadyn P. Transcriptomic responses to wounding: meta-analysis of gene expression microarray data. BMC Genomics. 2017:18(1):850. https://doi.org/10.1186/s12864-017-4202-8.

22. Anwar Y, Sabir JS, Qureshi MI, Saini KS. 5-lipoxygenase: a promising drug target against inflammatory diseases-biochemical and pharmacological regulation. Curr Drug Targets. 2014;15(4):410-22. https://doi.org/10.2174/13 89450114666131209110745.

23. Pan SC, Li CY, Kuo CY, Kuo YZ, Fang WY, Huang YH, et al. The p53-S100A2 positive feedback loop negatively regulates epithelialization in cutaneous wound healing. Sci Rep. 2018;8(1):5458. https://doi.org/10.1038/s41598-01 8-23697-5.

24. Burke SJ, Collier JJ. The gene encoding cyclooxygenase-2 is regulated by IL1 beta and prostaglandins in 832/13 rat insulinoma cells. Cell Immunol. 2011; 271(2):379-84. https://doi.org/10.1016/j.cellimm.2011.08.004.

25. Diaz-Munoz MD, Osma-Garcia IC, Fresno M, Iniguez MA. Involvement of PGE2 and the CAMP signalling pathway in the up-regulation of COX-2 and mPGES-1 expression in LPS-activated macrophages. Biochem J. 2012;443(2): 451-61. https://doi.org/10.1042/BJ20111052

26. Montero A, Uda S, Munger KA, Badr KF. LTA4 hydrolase expression during glomerular inflammation: correlation of immunohistochemical localization with cytokine regulation. Adv Exp Med Biol. 1999;469:449-54. https://doi. org/10.1007/978-1-4615-4793-8_66.

27. Arguello M, Paz S, Hernandez E, Corriveau-Bourque C, Fawaz LM, Hiscott J, et al. Leukotriene A4 hydrolase expression in PEL cells is regulated at the transcriptional level and leads to increased leukotriene B4 production. J Immunol. 2006;176(11):7051-61. https://doi.org/10.4049/ jimmunol.176.11.7051.

28. Kelner MJ, Bagnell RD, Montoya MA, Estes LA, Forsberg L, Morgenstern R, Structural organization of the microsomal glutathione S-transferase gene (MGST1) on chromosome 12p13.1-13.2. Identification of the correct promoter region and demonstration of transcriptional regulation in response to oxidative stress. J Biol Chem. 2000;275(17):13000-6. https://doi. org/10.1074/jbc.275.17.13000.

29. Vo $T \mathrm{TL}$, Jang $\mathrm{WJ}$, Jeong $\mathrm{CH}$. Leukotriene $\mathrm{A} 4$ hydrolase: an emerging target of natural products for cancer chemoprevention and chemotherapy. Ann N Y Acad Sci. 2018;1431(1):3-13. https://doi.org/10.1111/nyas.13929.

30. Landa P, Kutil Z, Temml V, Malik J, Kokoska L, Widowitz U, et al. Inhibition of in vitro leukotriene B4 biosynthesis in human neutrophil granulocytes and docking studies of natural quinones. Nat Prod Commun. 2013;8(1):105-8. https://doi.org/10.1177/1934578X1300800124.

31. Hayes JD, Pulford DJ. The glutathione S-transferase supergene family: regulation of GST and the contribution of the isoenzymes to cancer chemoprotection and drug resistance. Crit Rev Biochem Mol Biol. 1995; 30(6):445-600. https://doi.org/10.3109/10409239509083491.

32. Hayes JD, Strange RC. Potential contribution of the glutathione S-transferase supergene family to resistance to oxidative stress. Free Radic Res. 1995;22(3): 193-207. https://doi.org/10.3109/10715769509147539.

33. Gessner DK, Schlegel G, Keller J, Schwarz FJ, Ringseis R, Eder K. Expression of target genes of nuclear factor E2-related factor 2 in the liver of dairy cows in the transition period and at different stages of lactation. J Dairy Sci. 2013; 96(2):1038-43. https://doi.org/10.3168/jds.2012-5967.

34. Zhang H, Liu H, Dickinson DA, Liu RM, Postlethwait EM, Laperche $Y$, et al. Gamma-Glutamyl transpeptidase is induced by 4-hydroxynonenal via EpRE/ Nrf2 signaling in rat epithelial type II cells. Free Radic Biol Med. 2006;40(8): 1281-92. https://doi.org/10.1016/j.freeradbiomed.2005.11.005. 
35. Reuter S, Schnekenburger M, Cristofanon S, Buck I, Teiten MH, Daubeuf S, et al. Tumor necrosis factor alpha induces gamma-glutamyltransferase expression via nuclear factor-kappaB in cooperation with Sp1. Biochem Pharmacol. 2009;77(3):397-411. https://doi.org/10.1016/j.bcp.2008.09.041.

36. Yaekashiwa $M$, Wang $L H$. Nrf2 regulates thromboxane synthase gene expression in human lung cells. DNA Cell Biol. 2003;22(8):479-87. https://doi. org/10.1089/10445490360708883.

37. Sanchez-Rodriguez R, Torres-Mena JE, Quintanar-Jurado V, Chagoya-Hazas V, Rojas Del Castillo E, Del Pozo YL, et al. Ptgr1 expression is regulated by NRF2 in rat hepatocarcinogenesis and promotes cell proliferation and resistance to oxidative stress. Free Radic Biol Med. 2017;102:87-99. https:// doi.org/10.1016/j.freeradbiomed.2016.11.027.

38. Hosur V, Burzenski LM, Stearns TM, Farley ML, Sundberg JP, Wiles MV, et al. Early induction of NRF2 antioxidant pathway by RHBDF2 mediates rapid cutaneous wound healing. Exp Mol Pathol. 2017;102(2):337-46. https://doi. org/10.1016/j.yexmp.2017.03.003.

39. Bayele HK, Balesaria S, Srai SK. Phytoestrogens modulate hepcidin expression by Nrf2: implications for dietary control of iron absorption. Free Radic Biol Med. 2015;89:1192-202. https://doi.org/10.1016/j.freeradbiomed.2 015.11.001.

40. Bayele HK, Debnam ES, Srai KS. Nrf2 transcriptional derepression from Keap1 by dietary polyphenols. Biochem Biophys Res Commun. 2016;469(3):521-8. https://doi.org/10.1016/j.bbrc.2015.11.103.

41. Onasanwo SA, Velagapudi R, El-Bakoush A, Olajide OA. Inhibition of neuroinflammation in BV2 microglia by the biflavonoid kolaviron is dependent on the Nrf2/ARE antioxidant protective mechanism. Mol Cell Biochem. 2016;414(1-2):23-36. https://doi.org/10.1007/s11010-016-2655-8.

42. Mascuch SJ, Boudreau PD, Carland TM, Pierce NT, Olson J, Hensler ME, et al. Marine natural product Honaucin a attenuates inflammation by activating the Nrf2-ARE pathway. J Nat Prod. 2018;81(3):506-14. https://doi.org/10.1 021/acs.jnatprod.7b00734.

43. Sgarbossa A, Dal Bosco M, Pressi G, Cuzzocrea S, Dal Toso R, Menegazzi M. Phenylpropanoid glycosides from plant cell cultures induce heme oxygenase 1 gene expression in a human keratinocyte cell line by affecting the balance of NRF2 and BACH1 transcription factors. Chem Biol Interact. 2012;199(2):87-95. https://doi.org/10.1016/j.cbi.2012.06.006.

44. Lee S, Choi SY, Choo YY, Kim O, Tran PT, Dao CT, et al. Sappanone a exhibits antiinflammatory effects via modulation of Nrf2 and NF-kappaB. Int Immunopharmacol. 2015;28(1):328-36. https://doi.org/10.1016/j.intimp.2015.06.015.

45. Kim JE, Lee KW. Molecular targets of phytochemicals for skin inflammation Curr Pharm Des. 2018;24(14):1533-50. https://doi.org/10.2174/1381612824 666180426113247

46. Michalak M, Pierzak M, Krecisz B, Suliga E. Bioactive Compounds for Skin Health: A Review. Nutrients. 2021;13(1):203.

47. Piipponen M, Li D, Landen NX. The Immune Functions of Keratinocytes in Skin Wound Healing. Int J Mol Sci. 2020;21(22):8790. https://doi.org/10.3390/ ijms21228790.

48. Wang ZC, Zhao WY, Cao Y, Liu YQ, Sun Q, Shi P, et al. The roles of inflammation in keloid and hypertrophic scars. Front Immunol. 2020;11: 603187. https://doi.org/10.3389/fimmu.2020.603187.

49. Gupta A, Dai T, Hamblin MR. Effect of red and near-infrared wavelengths on low-level laser (light) therapy-induced healing of partial-thickness dermal abrasion in mice. Lasers Med Sci. 2014;29(1):257-65. https://doi.org/10.1007/ s10103-013-1319-0.

50. Chomczynski P, Mackey K. Short technical reports. Modification of the TRI reagent procedure for isolation of RNA from polysaccharide- and proteoglycan-rich sources. Biotechniques. 1995;19(6):942-5.

51. Lipson D, Raz T, Kieu A, Jones DR, Giladi E, Thayer E, et al. Quantification of the yeast transcriptome by single-molecule sequencing. Nat Biotechnol. 2009;27(7):652-8. https://doi.org/10.1038/nbt.1551.

52. Kapranov P, St Laurent G, Raz T, Ozsolak F, Reynolds CP, Sorensen PH, et al. The majority of total nuclear-encoded non-ribosomal RNA in a human cell is 'dark matter' un-annotated RNA. BMC Biol. 2010;8(1):149. https://doi.org/1 0.1186/1741-7007-8-149.

53. Rao MS, Van Vleet TR, Ciurlionis R, Buck WR, Mittelstadt SW, Blomme EAG, et al. Comparison of RNA-Seq and microarray gene expression platforms for the Toxicogenomic evaluation of liver from short-term rat toxicity studies. Front Genet. 2018;9:636

54. Love Ml, Huber W, Anders S. Moderated estimation of fold change and dispersion for RNA-seq data with DESeq2. Genome Biol. 2014;15(12):550. https://doi.org/10.1186/s13059-014-0550-8.
55. Harris MA, Clark J, Ireland A, Lomax J, Ashburner M, Foulger R, et al. The gene ontology (GO) database and informatics resource. Nucleic Acids Res. 2004;32(Database issue):D258-61. https://doi.org/10.1093/nar/gkh036.

\section{Publisher's Note}

Springer Nature remains neutral with regard to jurisdictional claims in published maps and institutional affiliations.
Ready to submit your research? Choose BMC and benefit from:

- fast, convenient online submission

- thorough peer review by experienced researchers in your field

- rapid publication on acceptance

- support for research data, including large and complex data types

- gold Open Access which fosters wider collaboration and increased citations

- maximum visibility for your research: over $100 \mathrm{M}$ website views per year

At $\mathrm{BMC}$, research is always in progress.

Learn more biomedcentral.com/submissions 